Nordisk Tidsskrift for Kriminalvidenskab 2011

\title{
DE NORDISKE KRIMINALISTFORENINGER 2010
}

\section{Dansk Kriminalistforening}

Foreningens formand er direktør William Rentzmann. Sekretær og kasserer advokat Bjørn Høberg-Petersen. Bestyrelsen bestod i 2010 endvidere af professor Flemming Balvig, overlæge Peter Kramp, forskningschef Britta Kyvsgaard, departementschef Michael Lunn, professor Gorm Toftegaard Nielsen, rigsadvokat Jørgen Steen Sørensen, højesteretsdommer Poul Dahl Jensen, arrestinspektør Jens Tolstrup, fuldmægtig Susanne Clausen, professor Thomas Elholm, vicepolitidirektør Arne Vedsted Gram, og retspræsident Birgitte Holmberg-Petersen. De tre sidstnævnte blev valgt ind i bestyrelsen ved generalforsamlingen i februar, og erstattede medlemmerne Vagn Greve, Peter Garde og Lars Rand der alle faldt for aldersgrænsen på 70 år.

Årsmødet i foreningen fandt sted den 6. februar 2011.

Efter generalforsamlingen holdt sociolog Christian Klement og politidirektør i NEC, Kim Kliver, oplæg om henholdsvis "Bander og rockere. Hvilke risikofaktorer karakteriserer dem? Adskiller de sig fra andre kriminelle?" og "Bandekonflikterne- dens aspekter, indsatsen og resultaterne".

Bestyrelsens hovedopgave i 2010 var at afholde det 15. Nordiske Kriminalistmøde i København i august. Konferencen forløb over 3 dage (fra den 19. - 21. august) med i alt 31 oplægsholder og 173 deltagere. Konferencen havde et meget højt fagligt niveau og forløb meget fint. Foreningen har efterfølgende modtaget mange positive tilbagemeldinger fra både deltagere og oplægsholdere. De oplæg der blev holdt på konferencen er alle at finde i NTfK (2010:3).

Dansk Kriminologisk Selskab, der er et datterselskab til Dansk Kriminalistforening, arrangerede fem møder i 2010. Den 17. marts indledte Folketingets Ombudsmand Hans Gammeltolft-Hansen om "Ombudsmandens kontrolfunktion med fængslerne". Den 3. juni indledte overlæge Peter Kramp om "Samarbejdet mellem Den fri Kriminalforsorg og retspsykiatrien" (på grundlag af en helt ny undersøgelse). Den 6. september indledte Ph.D. Linda Kjær Minke om "Prisonisering/fangekulturen" på baggrund af sin Ph.D. afhandling, som bl.a. bygger på feltstudier i Statsfængslet i Vridsløselille, og den 8. december indledte Statsadvokat Jens Madsen, SØK, om "Bekæmpelse af økonomisk kriminalitet. Desuden deltog vicedirektør i Finanstilsynet, Hanne Råe, om "Tilsynets kontrolvirksomhed i forbindelse med værdipapirhandel/insiderhandel".

Den 14. december afholdte Selskabets fynske afdeling i samarbejde med Juridisk Institut, Syddansk Universitet, arrangement med oplæg af politidirektør ved Københavns Politi, Johan Reimann. Oplægget handlede om ungdomskriminalitet, 
bandekriminalitet, kriminalitetsforebyggelse og arbejdet i regeringens ungdomskommission, som Reimann var formand for.

Dansk Selskab for International Strafferet og EU-ret, der også er et datterselskab til Dansk Kriminalistforening, har i 2010 holdt ét møde. Den 28. april indledte Morten Niels Jakobsen, kontorchef, Det internationale kontor, Justitsministeriet om "EU's politimæssige og strafferetlige samarbejde efter Lissabon-traktaten".

Ved årets udgang havde Dansk Kriminalistforening 358 medlemmer.

\section{Kriminalistforeningen i Sverige}

Vid Kriminalistföreningens årsmötet den 3 maj 2010 omvaldes styrelseledamöterna Jan Andersson, Gudrun Antemar, Agneta Bäcklund, Sten Heckscher, Owe Horned, Peter Lindström, Tomas Rothpfeffer, Bengt Svensson, Magnus Ulväng och Fredrik Wersäll. Till nya styrelseledamöter valdes Jerzy Sarnecki och Malena Carlstedt (kassör och sekreterare). Lotta Gustavson och Annika Lowén omvaldes som revisorer. Patrik Örnsved omvaldes som revisorssuppleant.

Styrelsen har under året sammanträtt tre gånger. I samband med föreningens årsmöte anordnades en kriminalpolitisk debatt mellan Beatrice Ask (M) och Thomas Bodström (S). Moderator var hovrättspresidenten Fredrik Wersäll. På föreningens vårpub talade lagmannen Stefan Strömberg på temat: Ägnar sig rättsväsendet åt rätt saker i rätt omfattning? Några funderingar om utvecklingen i rättsväsendet. På höstpuben talade Leif GW Persson på temat: Varför blir cold cases kalla?

Under året har föreningen genomfört en rensning i medlemsregistret vilket har minskat medlemsantalet. Den 31 december 2010 hade föreningen ca 180 medlemmar.

\section{Kriminalistforeningen i Island - Sakfræðifélag Íslands}

Foreningens formand er professor Ragnheiður Bragadóttir.

I 2010 afholdt foreningen tre møder, alle i samarbejde med andre institutioner.

Den 20. oktober arrangerede foreningen et møde i samarbejde med Det Juridiske Institut, Islands Universitet. På mødet holdt professor Vagn Greve en forelæsning med titlen: Trends in modern criminal law politics. Ordstyrer var Ragnheiður Bragadóttir. Til stede var 45 gæster.

Den 10. november holdt foreningen et møde i samarbejde med Det Juridiske Institut, Islands Universitet. På mødet holdt lic jur. Beth Grothe Nielsen en forelæsning med navnet: Lolita - A stereotype for the victimized girl. Ordstyrer var Ragnheiður Bragadóttir. Til stede var 35 gæster.

Den 26. november arrangerede foreningen et debatmøde i samarbejde med Islands Juristforening om temaet: Udviklingen i strafudmåling for seksualfor- 
brydelser. Er domstolene ramt af kritik? Indledere var professorene Ragnheiður Bragadóttir og Helgi Gunnlaugsson. Ordstyrer var Ólafur Pór Hauksson special statsadvokat. Til stede var 35 gæster.

\section{Kriminalistföreningen i Finland - Suomen Kriminalistiyhdistys}

Föreningens styrelse har under redogörelseåret haft följande sammansättning; ordförande: docent Jussi Matikkala, viceordförande: generaldirektör Esa Vesterbacka, sekreterare och kassör: jur. kand. Dan Helenius. Styrelsens övriga medlemmar bestod av följande personer: överläkare Aulikki Ahlgren, vicechef Sanna Heikinheimo, domare vid Europeiska människorättsdomstolen Päivi Hirvelä, professor (tf.) Sakari Melander, specialsakkunnig Henrik Linderborg, överlärare Matti Laine, institutionschef Tapio Lappi-Seppälä, föredragande Kaarlo Hakamies, hovrättsråd Tuomas Nurmi, advokat Jouko Pelkonen, justitieråd Pekka Koponen, generalsekreterare Hannu Takala och lagstiftningsdirektör Asko Välimaa. Styrelsen sammanträdde två gånger år 2010; den 10 maj och den 17 november. Jur.kand. Lauri Rautio har även varit studentmedlem i styrelsen.

Professor Inkeri Anttila är hedersmedlem i föreningen.

Föreningens årsmöte hölls den 19 april 2010. Temat för mötet var "Aktuellt om korruption och dess bekämpning". Inledningsanföranden till diskussionen hölls av lagstiftningsråd Ilari Hannula och direktör Mika Winqvist.

Föreningens höstmöte hölls den 18 november 2010. Temat för mötet var "Straff och vård inom sexualstraffrätten". Professor Terttu Utriainen höll ett anförande om sexualbrottens påföljder och överdirektör Jarmo Littunen om den planerade förpliktande läkemedelsbehandlingen för sexualbrottslingar.

Vid årets slut hade föreningen 252 medlemmar.

\section{Norsk Kriminalistforening}

Årsmøtet 2010 ble holdt 10. mars 2010 på Institutt for offentlig rett, Juridisk fakultet i Oslo. Årsberetning og regnskap for 2009 ble godkjent.

I samsvar med innstilling fra valgkomiteen ble følgende styre valgt: Lagdommer Anne-Mette Dyrnes, Borgarting lagmannsrett (leder) Juridisk rådgiver Guro Kleppe, Spesialenheten for politisaker (nestleder) Post doc Jørn R.T. Jacobsen, Juridisk fakultet, Universitetet i Bergen (styremedlem)

Avdelingsdirektør Knut Erik Sæther, Lovavdelingen i Justisdepartementet (styremedlem)

Advokat Arne Gunnar Aas, Advokatfirmaet Hjort (styremedlem)

Forsker Jane Dullum, Institutt for kriminologi og rettssosiologi, Universitetet i Oslo (vara) 
Direktør Tor Langbach, Domstoladministrasjonen (vara)

Roar Østby, PWC, ble gjenvalgt som revisor. Valgkomiteen, bestående av professor Ulf Stridbeck og lagdommer Anne M. Samuelson, ble også gjenvalgt.

Stipendiat Synnøve Ugelvik - sekretær for styret fra høsten 2009 - ga våren 2010 beskjed om at hun ønsket å fratre på grunn av stor arbeidsbelastning. Dommerfullmektig Anette Tandberg, Oslo tingrett, overtok som sekretær høsten 2010.

De siste årene har det vært lite kontinuitet i sekretærfunksjonen. Styret antar at dette først og fremst skyldes at arbeidet med ajourføring av medlemsregisteret og innkreving av kontingent har vært for tidkrevende.

Styret vedtok 7. juni at sekretæren skal honoreres med 4000 kroner pr år. For å effektivisere og kvalitetssikre arbeidet med innkreving av kontingent benyttes Medlemsservice.no fra høsten 2010. Styret har hatt kontakt med foreningen Nordisk administrativt samfunn som benytter denne tjenesten og har gode erfaringer med den. Oppdatering av registeret må fortsatt gjøre manuelt av sekretæren, mens innkreving/purring og registrering av betalinger skjer via Medlemsservice.no.

Tjenesten ble første gang benyttet til purring høsten 2010. Det viste seg fortsatt å være feil i medlemsregisteret slik at det ble sendt purring til medlemmer som hadde betalt og til folk som hadde meldt seg ut. Arbeidet med å få registeret à jour må kontinuerlig gis høy prioritet.

Foreningen har arrangert to debattmøter.

Tema for møtet etter årsmøtet 2010 var "Advokatens taushetsplikt". Innledere var leder for Advokatforeningen, Berit Reiss Andersen og Økokrim-sjef Trond Eirik Schea. Møtet fant sted i møterommet på Institutt for offentlig rett, Juridisk fakultet.

Den 10. november 2010 var "Tigging" tema for debattmøtet. Innledere var byrådsleder i Oslo, Stian Berger Røsland, generalsekretær Sturla Stålsett, Kirkens bymisjon, og professor Tor-Geir Myhrer, Politihøyskolen. Møtet ble holdt på Litteraturhuset i Oslo.

Den norske kriminalistforeningen deltok på Det nordiske kriminalistmøtet som ble holdt i København 19-21 august med bortimot 200 deltakere. Det var 38 deltakere fra Norge, herunder sju foredragsholdere. På møtet ble det bestemt at Det nordiske kriminalistmøtet 2013 skal holdes i Oslo i regi av den norske foreningen.

Det har vært avholdt tre styremøter. Styrets leder har hatt tre møter med sekretær(ene). Ellers har synspunkter og ideer blitt utvekslet per e-post.

$\operatorname{Pr} 4$. november 2010 hadde foreningen 214 medlemmer.

På årsmøtet 2008 ble det besluttet å opprette en forsøksordning med lokalavde- 
ling i Trøndelag. Ordningen skulle evalueres i 2010. Det er ikke opprettet noen lokalavdeling.

Foreningen mottok støtte fra advokatfirmaene Hjort og Elden med 5000 kroner fra hver i 2010. Pengene benyttes til dekning av utgifter til debattmøtene. 